\title{
Attitudes, subjective norms, and perceived control versus contextual factors influencing the entrepreneurial intentions of students from Poland
}

\author{
URSZULA KOBYLIŃSKA \\ Faculty of Engineering Management \\ Bialystok University of Technology \\ 45A Wiejska Street, Bialystok 15-351 \\ POLAND
}

\begin{abstract}
Purpose: The article analyses the influence of personal and contextual variables on entrepreneurial intentions of students from Poland. The article presents a structural model that has been developed from a set of student perceptions. Chosen variables included in the model allows explaining and managing the formation of the intention in the context of higher education. This study provides answers to the following questions: What role and which personal variables do play importance in the formation of entrepreneurship intention in the case of young people? Which and how contextual variables are important to enhance personal variables for entrepreneurial intentions?

Methodology: The research was carried out by using critical literature analysis as well as statistical research. In carrying out this work, a causal quantitative methodology (structural equation modeling) was applied using the Amos program. Factor analysis has also been used in a descriptive methodological context. The empirical research was conducted in first quarter of 2020.

Findings: Research conducted on a sample of over 330 Polish students has shown that not all personal factors are statistically significant in assessing the entrepreneurial intentions of young people. As the results show, subjective norms do not play a significant role in the intention to take up self-employment. External (contextual) factors related to the broadly understood environment supporting the future entrepreneur play an important role, but much less clear than the factors at the individual level and generally indirectly influence entrepreneurial intentions, strengthening the entrepreneur's personal factors.

Practical Implications: The results suppose a theoretical and practical contribution to the promotion of entrepreneur intentions of university students inside and outside the educational context. Entrepreneurship promotion programmes run by universities must focus on developing the attitude of the potential entrepreneurs, conveying the message that, despite all the obstacles that exist when launching a business, the entrepreneurship route can be an interesting alternative.

Originality/Value: In the study, the personal and contextual factors influencing the entrepreneurial intentions of students were taken into account. The causal model generated on a sample of 332 Polish respondents shows the importance of individual factors on entrepreneurial intentions and the impact of contextual constructs on personal factors. Contextual variables (i.e. education, public policy, supporting entrepreneurial environments) were found to have a positive impact on personal variables as well as entrepreneurial intentions.
\end{abstract}

Key-Words: entrepreneurial intention, Theory of Planned Behaviour (TPB), personal and contextual factors

Received: June 21, 2021. Revised: December 20, 2021. Accepted: January 5, 2022. Published: January 7, 2022.

\section{Introduction}

The literature on the subject confirms the need to identify and strengthen the factors determining the process of establishing new companies, due to the high impact of entrepreneurship on the economic development of countries and regions [1] and the significant role limiting unemployment through job creation and self-employment. Researchers took into account the important role that entrepreneurship plays in economic development and began to study the factors that influence people to become entrepreneurs [2]. Reports and documents prepared periodically by the Global Entrepreneurship Monitor confirm that these factors are of an eminently personal and contextual nature [3]. The Shapero and Sokol (1982) model of an entrepreneurial event [4] and the Ajzen $(1987,1991)$ model of planned behavior $[5,6]$ are the two most tested theories that have been used in many studies to explain entrepreneurial intentions. Intent models are successfully implemented not only in social psychology, but also in marketing and management [7]. The models faced some criticism and several authors emphasized the importance of further clarifying the role played by some personal variables such as motivation 
[8] or of in-depth analysis of external factors such as political support, education, a supportive business environment in the region or country.

Since intentions have been shown to be a strong predictor of actual future behavior [9], many studies have sought to determine which factors positively influence entrepreneurial intentions (EI) [10]. In addition, intent is the best predictor of individual behavior, especially when it is rare, difficult to observe or involves unpredictable time delays [11]. As noted in previous studies, entrepreneurial intentions indicate how well prepared you are and how much effort you intend to put in to implement entrepreneurial behavior. When people have considerable potential, they will refrain from turning to entrepreneurship when they have no intention.

In recent years, a number of articles have been published in this area of research identifying various factors that precede entrepreneurial intentions, both individual and contextual. One of the areas where many of these studies are undertaken is higher education. It is now generally accepted that education is essential to the creation of an entrepreneurial individual and therefore an entrepreneurial community. Universities are pillars of knowledge that provide students with the skills needed to develop entrepreneurial tendencies [12]. Earlier studies in this context analyzed the role of students' personal and environmental factors in shaping their entrepreneurial intentions, but the results of these studies remain contradictory [13-14]. The question is what factors influence entrepreneurial intentions among students.

The aim of the study described in this article is to investigate the impact that certain variables, identified as important in research on entrepreneurial intentions in other countries, have on the intentions of students in Poland. The article presents the results of a survey conducted among 332 students of Bialystok University of Technology. The aim is to answer the question which variables classified as personal and contextual have an impact on entrepreneurial intentions among students. In particular, the study of the importance of contextual factors (indirectly influencing entrepreneurial intentions) (i.e. perceived educational, governmental, institutional support) is a contribution of this study.

The author chose the TBM model as the theoretical basis for empirical research due to the benefits it offers in the academic environment [15-16]. In the TBM model, a person's behavior is immediately determined by his intention to perform (or not) that behavior. In turn, the intention (EI) of behavior depends on three elements: first, an entrepreneurial attitude (EA); secondly, the subjective norm (SN), which implies the belief of a person about the presence of social pressure on him, that he should perform or not perform a specific activity and the motivation to satisfy these pressures; and third, the perceived behavioral control (PC) they have in a situation where they need to make a decision and act. Previously conducted studies described in the literature using TBM to explain entrepreneurial attitudes suggest that EA, SN and PC usually explain $30-45 \%$ of the variance of intentions [17].

In particular, the aim of this study is to analyze how the entrepreneurial intentions of students in Poland are shaped, bearing in mind that general entrepreneurship literature usually identifies specific domains (e.g. personality traits, intrinsic motivation and previous experiences) and contextual variables (e.g. social, economic or political context) as the two main dimensions responsible for the formation of EI $[9,18]$.

Research results on a sample of over 330 students from Poland (studying at the Faculty of Management Engineering/Bialystok University of Technology) has shown that not all individual factors are statistically significant in assessing the entrepreneurial plans of young people. As the results show, subjective norms do not play a significant role in the intention to take up selfemployment. External (contextual) factors related to the broadly understood environment of the future entrepreneur play an important role, but much less clear than the factors at the individual level and generally indirectly influence entrepreneurial intentions, strengthening the entrepreneur's individual factors.

The article is part of the research trend in which it is possible to observe the need for further analysis of entrepreneurial intentions in the context of the student environment, using a combination of individual and contextual factors influencing their willingness to become an entrepreneur. 


\section{Theoretical background}

As indicated in the literature, entrepreneurial intention (EI) is a state of mind leading to the choice of self-employment over working for someone else. Many studies, such as: [19,20] analyze the positive relationship between EI and entrepreneurial activity, as well as its subsequent relationship with economic development.

A lot of interest in researching entrepreneurial intentions is related to many factors. As research shows, intention has a strong correlation with the behavior of creating a firm; in some cases, this correlation even exceeded 0.96 [21]. Intention also explains the high percentage of the variance in entrepreneurial behavior, and it is the variable that most accurately predicts entrepreneurial behavior [21,22]. On the other hand, intention is a measure of the will and personal effort an entrepreneur is willing to undertake to start a business [23,24].

There are two models that serve as a guide to understanding the development of entrepreneurial intentions: Shapero and Sokola's (1982) business event model (EEM) for a business event [4], and Ajzen's planned behavior (TPB) theory $(1991)[5,6]$. In the Shapero and Sokol model, the intention of entrepreneurship is shaped on the basis of perceived desire, perceived vitality and propensity to act. Planned action theory, on the other hand, holds that the intention to start an activity depends on three variables: attitude to behavior, perceived control of behavior, and subjective norm.

Intent-based models are the subject of much research in the fields of psychology, marketing, and management, and previous research has revealed very interesting empirical conclusions. Due to the predictive power of intention over entrepreneurial behavior, entrepreneurial intention was used as a dependent variable in most of the designed models [9,25]. Although both models have been empirically tested and provide satisfactory predictions of entrepreneurial intentions, the use of planned behavior theory is dominant in the literature [9].

The most influential articles on entrepreneurial intention can be divided into several groups. The first category includes publications dealing with theoretical and methodological issues testing major models. The second category includes articles focusing on variables such as gender, family roles, social capital, and personality traits. The third group of research concerns the role of education in the context of entrepreneurship. Numerous publications focus on the role of context and institutions, including samples from several countries. The last group of articles analyzes the relationship between intention and behavior, confirming the high predictive potential of intention in entrepreneurial behavior [26].

Despite the research and findings, there are a number of reasons why there is a need to deepen the research on entrepreneurial intentions, especially in the case of young people, because there is a consensus in the literature about personal factors influencing their entrepreneurial intentions, and on the other hand discrepancies in relation to other factors (e.g. contextual) $[27,28]$. At the empirical level, the emphasis is primarily on enriching the models with significant variables influencing intentions [29]. Especially when new generations will make decisions about future careers.

In the literature, there is a need for a deeper analysis of contextual factors that may affect entrepreneurial attitudes of young people. The identification of socio-economic, educational, or political and legal factors may make people aware of the role of the environment that the governments of individual countries can influence in shaping an entrepreneur-friendly environment. At the contextual level, some researchers suggest deepening the understanding of how public institutions [30], the country's culture [31] or entities from the broadly understood support ecosystem [32] influence the entrepreneurial intentions of young people. There is also a need to investigate a possible causal relationship between certain education-related factors (e.g. the role of education, relevant university entrepreneurship courses) and factors that influence intentions and/or behavior (e.g. attitudes, values) [33]. Some researchers suggest the need for further comparative research into entrepreneurial intentions at the regional level and in the context of national / regional policy that builds a good support ecosystem for entrepreneurs [31,34].

Many researchers believe that although companies are created voluntarily and intentionally [35], the basis for the unconscious internalization of attitudes and values that will eventually force an entrepreneur to create a company is socialization [36]. This raises the need to determine to what extent entrepreneurial intentions and entrepreneurship are voluntary and conscious or conditioned processes, e.g. contextually through external support, access to 
education, etc., which in turn may affect specific personal variables and, consequently, entrepreneurial intentions and behavior.

\section{Conceptual model and hypotheses}

Considering the main theoretical and empirical relations discussed in the previous chapter and taking into account the literature review, the author proposes an explanatory model for Polish students' entrepreneurial intention based on their personal and contextual dimensions influencing the entrepreneurship process.

Below is Figure 1 of the concept model. This model is characterized and distinguished from other models by its simplification and practicality, as well as taking into account contextual variables (factors that make up the broadly understood ecosystem of entrepreneurship support, i.e. education, public policy, business environment). The model starts with personal (individual) factors that are crucial to the intention to become an entrepreneur. The model also shows the importance of contextual factors that indirectly affect the intentions and can largely shape the individual characteristics of the entrepreneur.

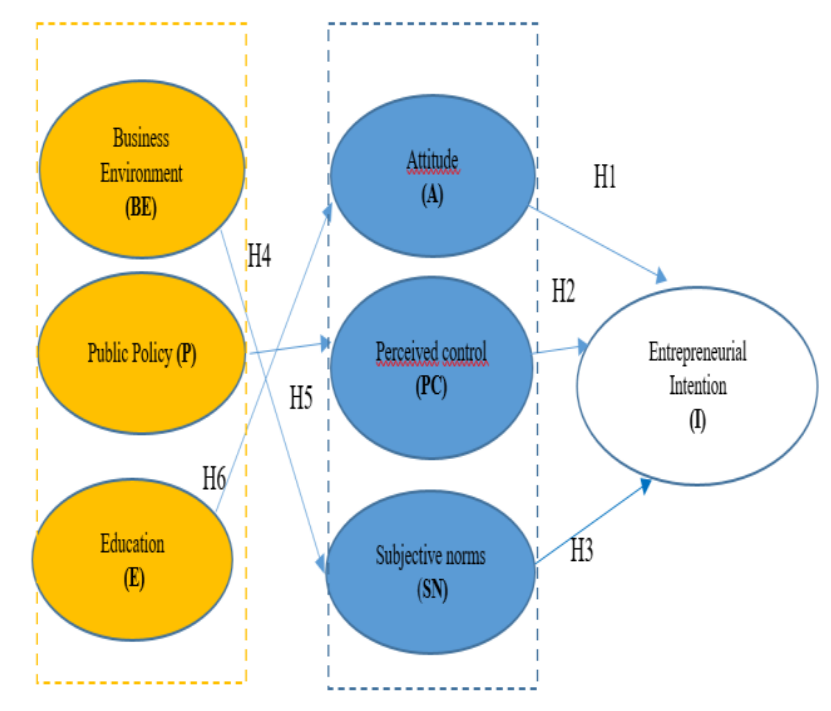

Figure 1. Conceptual model

Source: own research from the TPB model (closely related to the entrepreneur): entrepreneurial attitude (A), subjective norm (SN) and perceived control (PC). Analyzing the literature and the results of empirical research, it was noticed the need to take into account new variables in the model of entrepreneurial intentions, in particular the variable $\mathrm{BE}$ (business environment, otherwise business-friendly ecosystem) as a construct predictor (SN); public policy (PP) as a construct predictor (PC), and the education system (E) as a construct predictor (A). The relationships and rationale for including individual constructs in the model of entrepreneurial intentions are described below.

\subsection{Attitude (A) and entrepreneurial intention (I)}

Attitudes are closely related to the favourable predisposition of a person towards behaviour, in this case, the behaviour of creating a company $[37,38]$. The literature on people's attitudes to their own involvement in entrepreneurial activity suggests that they devote their efforts and time to entrepreneurship, if they perceive this activity as positive and professionally stimulating, and also having the potential to provide specific benefits, e.g. financial or social status [32,39].

In the models that explain the formation of entrepreneurial intention, attitudes influence the intention and behaviour through other, such as motivation and self-efficacy [40]. Specifically, in the educational context, it has been proven that the motivation to start a business are effectively influenced by attitudes of students towards entrepreneurship, and the attitude can explain $50 \%$ of the variance [13].

If students are sympathetic to entrepreneurial activities, it will mean a greater willingness to spend time and effort creating a new business. Therefore, the author make the following hypothesis:

H1: Attitude positively influences students' intention to become an entrepreneur
As the predecessors of individual factors (directly affecting entrepreneurial intentions), the author considers three personal variables

\subsection{Perceived control (PC) and entrepreneurial intention (I)}


This construct includes a sense of being capable (having the skills necessary to start a business and succeed in it), but also a belief in being able to control behavior [22].

Perceived behavioral control is influenced by beliefs about control, understood as assessing one's abilities in overcoming specific obstacles that may arise while setting up or driving companies. Taking the polish reality as an example, an individual may see it in bureaucracy or any obstacles that make it difficult for her to make a decision to set up a company or about entering the path of entrepreneurship. Such a group of perceived obstacles affects the overall assessment of the feasibility of a specific behavior, i.e. the perceived behavioral control [41].

The literature generally agrees that the perception of being in control is positively related to the intention to become an entrepreneur [32]. In this context, the following hypothesis was put forward:

\section{H2: PC positively influences students' intention} to become an entrepreneur

\subsection{Subjective norms (SN) and entrepreneurial intention (I)}

Scientific research shows that in the regions where there is a greater social acceptance for the implementation of entrepreneurial activities, a greater number of start-ups are created. This, in turn, translates into more companies that achieve success [42]. Not only the social perception of entrepreneurship, but also the assessment of this phenomenon expressed by family members may determine the occurrence entrepreneurial intentions. In the scientific literature, one can find the claim that starting and running your own business is impossible without getting support from the family. this is because its members interact very strongly [43].

The aforementioned support concerns not only substantive or managerial assistance, but also mental support manifested through acceptance decisions made and motivating to implement the decisions made. The unfavorable attitude of family members towards entrepreneurship often translates into reluctance to pursue an entrepreneurial career. Consequently, people entering the labor market perceives full-time employment as a more attractive path for the future career rather than starting your own companies [44]. Additional, the knowledge of support from friends and family leads to higher selfesteem and motivation to undergo an entrepreneurial path [45].

H3: Subjective norms positively influences students' intention to become an entrepreneur

\subsection{Business environment (BE) and subjective norms (SN)}

The willingness to remain an entrepreneur can also be explained by the influences of the business environment, i.e. a specific ecosystem supporting entrepreneurship. Isenberg defines such an ecosystem as "a set of cooperating institutions (...) in order to facilitate the entrepreneur's transition through all stages of the development process of a new venture". This can be understood as a network of services in which the entrepreneur is the center of action and a measure of success [46]. Researchers emphasize that it is important to characterize the local context (e.g. business environment conducive to entrepreneurship, availability of appropriate infrastructure, financial investors), and more specifically mechanisms supporting entrepreneurship [32]. These factors may have a positive impact on the entrepreneur's environment, which will be additionally supported by the family and relatives who will positively assess the entrepreneur's situation before starting a business and may indirectly influence the entrepreneur's intentions. In other words, a good business climate conducive to entrepreneurship will positively influence the attitude of people who are in the immediate vicinity of the entrepreneur (family and friends) and will support the entrepreneur in his activities.

H4: The business environment has a positive effect on subjective norms

\subsection{Public policy (PP) and perceived control (PC)}

Perceived behavioral control demonstrates a person's belief that he or she is capable of carrying out an action. It is influenced by the 
belief in one's own abilities, having certain characteristics and the availability of the necessary resources. The stronger the belief that you are able to run and manage your own business, the higher the level of entrepreneurial intention [41]. Ultimately, however, only adequate the compilation of these three factors gives rise to an entrepreneurial intention.

Entrepreneurial activities can also be explained by the influence of economic and legal policy in a given country. New endeavors however big or small are regulated by public or private institutions. Such regulations can cause a feeling of threat or opportunity for entrepreneurs. Severe regulations and procedures can cause a decline in entrepreneurship intention of young individuals. On the other side, encouraging conditions may increase the aptitude for such entrepreneurial activity [47].

The scientists emphasized that government policy, supporting entrepreneurs through various facilities, e.g. lowering taxes and bureaucracy, have a positive impact on their business activities. This influence will be particularly important for the perception of the control of his behavior by the entrepreneur, as he will feel more confident in achieving his goals when he is aware that the state can support him through various programs, subsidies or a stable economic situation. Therefore, the following hypothesis was put forward:

\section{H5: Public policy positively influences the perceived control}

\subsection{Education (E) and entrepreneurial attitude (A)}

Another variable that appears in the entrepreneurial intention model is entrepreneurial education. It is understood as any educational programs or processes that shape entrepreneurial attitudes and skills [48]. Despite the earlier inclusion of entrepreneurship-related issues in educational programs, training in this subject has become a common phenomenon only in recent years. There are several types of entrepreneurial education due to the stage of development and previous experiences of its recipients. Conducting entrepreneurial education is related to the perceived entrepreneurial effectiveness of a given person. This concept refers to the belief that a person can successfully carry out entrepreneurial tasks and perform the role of an entrepreneur. Research shows that entrepreneurial effectiveness obtained as a result of the process of entrepreneurial education may have a positive effect on the attitude and thus increase the entrepreneurial intention $[49,50]$. Therefore, the following hypothesis was put forward:

H6: Education (in area of entrepreneurship) positively influences students' attitude

\section{Methodology}

In carrying out this work, a causal quantitative methodology using structural equations (Structural Equation Modelling, SEM) using the Amos program was used. SEM model has been chosen for its advantages in the study of human behaviour, for its optimal predictive potential [51]. Factor analysis has also been used in a descriptive methodological context.

\subsection{Sample and data colections}

The sample consisted of young students from Poland, taking into account the suggestions of other authors regarding the importance of higher education in entrepreneurship and the need to deepen studies in this segment of the population. Many authors point out that university students are a segment of interest in research on entrepreneurship in general, and entrepreneurship intention in particular [52].

The sample was deliberately selected from among students of the Faculty of Management Engineering who study in business-related fields of study (management, production engineering, tourism and recreation, logistics) because in this context it is easier to approach and promote entrepreneurship.

For the distribution of the questionnaire among students, the days and hours were selected randomly from among those with the highest attendance of students in the classrooms, so that the number of students in the sample of each course was representative. The survey was handed over to the students of the Faculty of Management Engineering at the Bialystok University of Technology personally by the 
author of the study at the turn of January and February 2020.

Table 1 presents data on the sample of 332 respondents (161 men and 171 women). Students attending the following programs (in academic year 2019/2020) were involved in the study: Management, Engineering and Service Management, Logistics, Management and Production Engineering, Tourism and Recreation. The sample size meets the minimum rule of 10 times the number of observed variables (items) in quantitative research using a questionnaire (there were a total of 25 observed predictor items).

Table 1 Description of the sample

\begin{tabular}{|l|r|r|}
\hline Gender & $\begin{array}{c}\text { Number } \\
\text { of } \\
\text { students }\end{array}$ & \% \\
\hline Men & 161 & $48,5 \%$ \\
\hline Women & 171 & $51,5 \%$ \\
\hline Total & $\mathbf{3 3 2}$ & $\mathbf{1 0 0 \%}$ \\
\hline
\end{tabular}

Source: own research

\subsection{Measures and instrument}

To understand the factors influencing the entrepreneurial intentions of university students, the study used a quantitative method of data collection and analysis. The questionnaire was used to gather information, as is usually the case in this type of research. The survey consists of two parts; general questions (gender, field of study, year of study) and a part of 35 five-point Likert questions with 5 answer alternatives (1: strongly disagree, to 5 : strongly agree) related to the items constructs of the model. The items were taken from existing scales of previous studies. After the initial test, the final questionnaire contained 25 items. Elements corresponding to intention and personal variables were designed in accordance with the comments of [53]. To design elements related to contextual factors, the variables described in publications $[32,54]$ were suggested.

\section{Results}

The measurement model has been tested for reliability and validity using Alfa Cronbach. As can be seen in Table 2, Cronbach alpha for each construct ranged between 0,64 and 0,79, indicative good reliability among the indicators of each construction.

Table 1. Evaluation of the measurement model

\begin{tabular}{|l|c|}
\hline \multicolumn{1}{|c|}{ Construct } & Alfa Cronbach \\
\hline A (attitude) & 0,76 \\
\hline PC (Perceived control) & 0,72 \\
\hline SN (Subjective norm) & 0,71 \\
\hline I (Intention) & 0,79 \\
\hline BE (Business environment) & 0,72 \\
\hline PP (Public Policy) & 0,76 \\
\hline E (Education) & 0,64 \\
\hline
\end{tabular}

Source: own research

The fit indices for the model demonstrated acceptable values and spoke in favor of adopting the model (Table 3). The results revealed a $\chi^{2}$ of 747,2839 with a probability level of 0.00 . As the indicators show, the goodness-of-fit measures are satisfactory: $\mathrm{CFI}=0.8054$, RMSEA $=0.739$, HOELTER $(0.01)=143$.

The analysis showed that not all constructs classified as personal factors had a positive impact on students' intentions to become entrepreneurs. It can be concluded that 5 hypothesis of 6 have been confirmed positively (Tab.3). There is no significant relationship between SN and I.

Contextual features related to the broadly understood entrepreneurship support ecosystem affect the variables of the classic TPB construct of entrepreneurship, initiating a chain of effects that can reinforce attitudes, subjective norms, and perceived control, leading to greater intention for students to create a company.

Relations with greater weight (Tab. 3) occur among the perceived control (PC) and entrepreneurial intentions $(\mathrm{H} 2: \beta=0.783)$ and between education (E) and entrepreneurial attitude (H6: $\beta=0.308)$.

Table 2Model of the impact of personal and contextual factors on students' 


\section{entrepreneurial intentions - model parameters and fit indices}

\begin{tabular}{|l|c|c|c|}
\hline Hypothesis & $\begin{array}{c}\text { Standardized } \\
\text { Regression } \\
\text { Weights }\end{array}$ & $\mathbf{P}$ & $\begin{array}{c}\text { Hypotesis } \\
\text { status }\end{array}$ \\
\hline H1: A -> I &, 2718 &, 0000 & Accepted \\
\hline H2: PC->I &, 7831 &, 0000 & Accepted \\
\hline H3: SN->I &, 0078 & 0,885 & Rejected \\
\hline H4: BE->SN &, 1711 &, 0000 & Accepted \\
\hline H5: P->PC &, 1343 &, 0000 & Accepted \\
\hline H6: E->A &, 3084 &, 0000 & Accepted
\end{tabular}

Measures of fit of the structural model: Chi-square $=747,28$ $\mathrm{d}=234 \mathrm{p}=0.00 \quad \mathrm{CMIN} / \mathrm{DF}=2.80 \quad \mathrm{CFI}=0.805 \quad \mathrm{NFI}=0.85$ RMSEA $=0.739$ HOELTER. $01=143$

Source: own research

Figure 2 shows the results of the estimates made with structural model. The arrows indicate causal relationships, the number beside each is the respective standardized coefficient.

The model has proven its capacity as a conceptual framework because indicator $\mathrm{R}^{2}$ (coefficient of determination) is high $(0,69)$ - it explains $69 \%$ of the variance entrepreneurial intention of students (I).

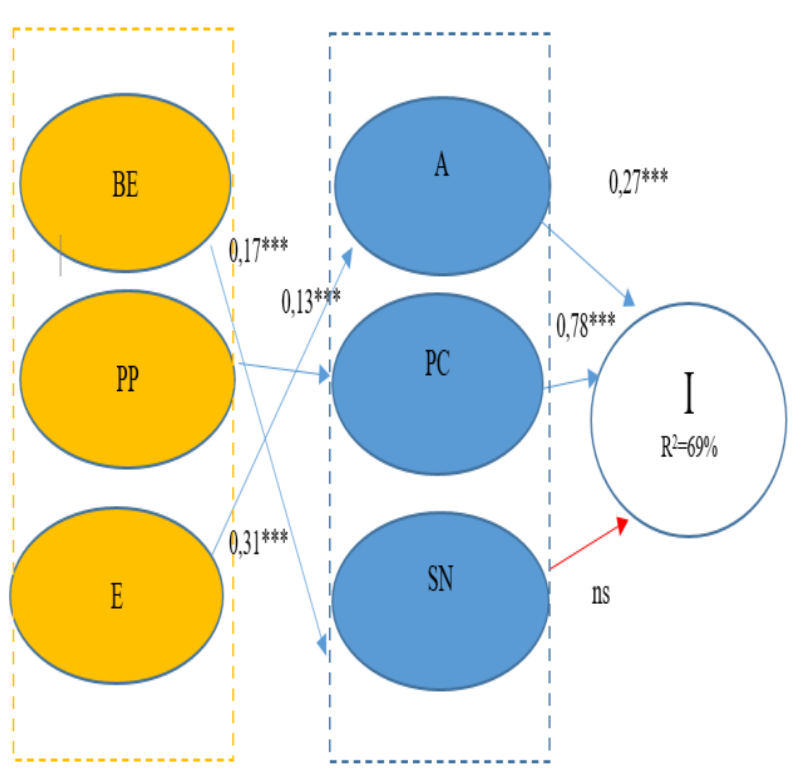

\author{
Figure 1 Structural model estimation \\ (****significant at ,0000, ns-non-significant) \\ Source: own research
}

Perceived control (PC) is a construct that contributes most towards explaining entrepreneurial intention, in particular item PC33: I would feel safe if I started a company $(0,7426)$ (Table 4). The other construct attitude (A) contributes less and and among its variables, item A29 was of the greatest importance $(0,8249)$ : I value entrepreneurship as a value. Construct - Subjective norms (SN) is not statistical significant.

In the case of contextual factors, their positive influence on personal factors was demonstrated. Education as a predictor of an entrepreneurial attitude showed the strongest relationship, especially in item E12: it is necessary to study entrepreneurship in universities (Table 4). Then, the statistical significance of the influence of business environment (BE) on subjective norms (SN) and public policy (PP) on perceived control (PC) was demonstrated.

Table 4 Construct, items and Standardized Regression Weights

\begin{tabular}{|ccc|}
\hline Construct & Item* & $\begin{array}{c}\text { Standardized } \\
\text { Regression } \\
\text { Weights }\end{array}$ \\
$\mathbf{A}$ & Q24A &, 5896 \\
& Q26A &, 4765 \\
& Q27A &, 7106 \\
& Q29A &, 8249 \\
PC & Q30PC &, 5779 \\
& Q31PC &, 6740 \\
& Q33PC &, 7426 \\
SN & Q25SN &, 8577 \\
& Q23SN &, 6707 \\
& Q18SN &, 4062 \\
I & Q35I &, 7059 \\
& Q19I &, 7485 \\
& Q16I &, 7454 \\
BE & Q15BE &, 5421 \\
& Q13BE &, 6214 \\
& Q11BE &, 7700 \\
& Q10BE &, 4429 \\
& Q8BE &, 5349 \\
PP & Q5PP &, 6886 \\
& Q4PP &, 7502 \\
\hline
\end{tabular}




\begin{tabular}{|ccc|}
\hline \multirow{4}{*}{$\mathbf{E}$} & Q2PP &, 5712 \\
& Q1PP &, 6667 \\
& Q14E &, 5349 \\
& Q12E &, 7692 \\
& Q3E &, 5568 \\
\hline
\end{tabular}

*detailed item names are included in appendix 1

Source: own research

\section{Discussion}

Understanding and being able to predict the formulation of entrepreneurial intentions becomes an important issue. Therefore, the article presents a synthesis of research on the determinants of the intention to start a business among students. Several categories of these determinants have been identified. Research results show that individual characteristics (personality, attitudes, beliefs, perceived control of behavior) influence the process of creating entrepreneurial intentions. However, research in the context of polish students of a selected university did not confirm the importance of subjective norms as directly explaining entrepreneurial intentions.

Taking into account the hypotheses put forward in the previous fragments of the article, there was only insufficient empirical evidence in the study to establish a significant relationship between SN and I (hypothesis 3), which contrasts with the results of previous research in the field of academic entrepreneurship [55, 1516], but it is in line with the results presented in the more general work on TPB-based EI [9].

It can be concluded that 5 hypothesis of 6 have been confirmed positively (Tab.4). The explanation for this result (that subjective norms were no important to entrepreneurial intentions) may be the lack of entrepreneurial culture in context of region, where survey were conducted. Podlasie province is a region in east part of Poland that historically has not been characterized by having a high rate of entrepreneurial activity.

Contextual features related to the broadly understood entrepreneurship support ecosystem affect the variables of the classic TBM construct of entrepreneurship, initiating a chain of effects that can reinforce attitudes, subjective norms, and perceived control, leading to greater intention for students to create a company.

On the other hand, the strongest positive relationships were observed for the influence of the PC variable on intention (I) $(\mathrm{H} 2: \beta=0.783)$ This is consistent with other research on entrepreneurial intentions [15-16,41,55]. High respondent ratings on the variable - Perceived control suggest that students consider themselves well-prepared to play the role of an entrepreneur, which can be the merit of a good education system in this area. It is also worth noting that the relationship between education and the entrepreneurial attitude is greater than in the case of other relations.

\section{Conclusions and implications}

The results showed that polish students entrepreneurial intentions to be explained by perceived control, and this in turn to be mainly influenced by public policy. As noted by [56] it may be possible that awareness of external support comes into play at later stages when individuals are actually implementing entrepreneurial actions. In order to carry out this process better and to achieve success, they might then start looking for external support.

The results have several implications for both academia and for managers in the education sector. First, this work contributes to the literature one entrepreneurial intentions since the study includes, in the academic context and within the TPB models, individual factors and contextual factors, demonstrating the special importance of variable - Attitude and its relationship with variable - E (education).

Second, the model suggests that intervention by public authorities to improve students intentions would have a indirect effect on their EI (by increasing their perceived control). It seems clear that a favourable entrepreneurial attitude depends primarily on the students personality. So, university managers must be aware that the best way of promoting entrepreneurial activity in their institutions is to create the conditions necessary to increase the entrepreneurial attitude of their students.

Moreover, entrepreneurship promotion programmes run by universities must focus on developing the attitude of the potential entrepreneurs, conveying the message that, despite all the obstacles that exist when launching a business, the entrepreneurship route can be an interesting alternative.

Despite the effort the author put into the design of the present study, it is not without limitations. Firstly, a common limitation of this type of study is that deriving from the self-selection bias. In particular, persons with a prior interest 
in self-employment are more likely to be attracted to respond to such a survey. Secondly, future research will need to analyze the passage from intention (I) to the action of creating a new business. While several studies such as this have analyzed the antecedents of entrepreneurial intention, fewer have considered the potential barriers that might hinder subsequent entrepreneurial actions. Also, an analysis of a longitudinal nature of a sample would determine whether intention (I) is eventually transformed into action. A thirdly, a study focuses on the intentions of students from the selected university, not the entire country or, for example, a geographic region. Data from different countries could be collected to compare intentions and behaviour students from various cultural and economic backgrounds. Additionally, there is no guarantee that students will convert intention into actual behaviour. Students who have shown a strong intention to adopt an entrepreneurial career path may choose to pursue it different direction. As suggested in the literature $[57,58]$, for example, further studies could be carried out on the same students after a few years to see if they changed their intention of behavior after graduation.

This study contributes to the literature by defining and identifying the importance of individual and contextual factors influencing entrepreneurial intentions among students. It differs from other studies in the literature, as it includes 3 groups of contextual variables indirectly influencing EI and reinforcing individual factors.

\section{Acknowledgment}

The publication is financed from the resources for science of Ministry of Science and Higher Education of the Republic of Poland under subsidies granted to the Faculty of Engineering Management of the Bialystok University of Technology.

\section{References:}

[1] Urbano, D., Aparicio, S., \& Audretsch, D. Twenty-five years of research on institutions, entrepreneurship, and economic growth: what has been learned? Small Business Economics, 2018, pp.1-29.

[2] Gelaidan, H.M. \& Abdullateef, A.O.. Entrepreneurial intentions of business students in Malaysia: The role of self-confidence, educational and relation support. Journal of Small Business and Enterprise Development, 2017, 24(1).

[3] Busenitz, L.W., Plummer, L.A., Klotz, A.C., Shahzad, A. \& Rhoads, K. Entrepreneurship research and the emergence of opportunities. Entrep. Theory Pract., 2014, No. 38, pp. 9811000.

[4] Shapero, A., \& Sokol, L.. The social dimensions of entrepreneurship. in: C. Kent, D. Sexton, and K. H. Vesper (Eds.), The Encyclopedia of Entrepreneurship, PrenticeHall, Englewood Cliffs, N J. 1982, pp. 72-90.

[5] Ajzen, I. Attitudes, traits \& actions: Dispositional prediction of behavior in personality and social psychology. Advances in Experimental Social Psychology, 1987, 1(20), pp. 1-63.

[6] Ajzen, I. The theory of planned behavior. Organizational Behavior and Human Decision Processes, 1991, 50(2), pp. 179-211.

[7] Wach, K., Wojciechowski, L. Entrepreneurial Intentions of Students in Poland in the View of Ajzen's Theory of Planned Behaviour. Entrepreneurial Business and Economics Review, 2016, No 4, pp. 83-94.

[8] Hien, D. T. T., \& Cho, S. E. The effect of software developers' capabilities on entrepreneurial intention in ICT industries. International Journal of Entrepreneurship, 2018, 22(3), pp.1-17.

[9] Krueger, N.F., Reilly, M.D., Carsrud, A.L. Competing models of entrepreneurial intentions, Journal of Business Venture, 2000, 15, pp. 411432.

[10] Kobylińska, U., Personal and Contextual Factors Affecting The Intentions of Commercialization of Research Results Among Academic Teachers of Technical Universities Concept of Model and Research Process, [in:] Proceedings of the 35th International Business Information Management Association Conference (IBIMA): Education Excellence and Innovation Management: A 2025 Vision to Sustain Economic Development during Global, Soliman Khalid S. (ed.), 2020, Seville, pp. 838846

[11]Krueger, N.F., Brazeal D.F. Entrepreneurial potential and potential entrepreneurs, Entrepreneurship Theory and Practice, 1994, 18(3), pp. 91-104.

[12] Volkmann, C., Fichter, K., Klofsten, M. Sustainable entrepreneurial ecosystems: an 
emerging field of research. Small Business Economics, 2019, pp. 1-9.

[13] Schwarz, E. J., Wdowiak, M. A., AlmerJarz, D. A., \& Breitenecker, R. J. The effects of attitudes and perceived environment conditions on students' entrepreneurial intent: An Austrian perspective. Education \& Training, 2009, 51(4), pp. 272-291.

[14] Nabi, G., Liñán, F. Fayolle, F. et al., The Impact of Entrepreneurship Education in Higher Education: A Systematic Review and Research Agenda, Academy of Management Learning \& Education, 2017,Vol. 16, No. 2.

[15] Goethner, M., Obschonka M., Silbereisen, R.K., Cantner U. Scientists' transition to academic entrepreneurship: Economic and psychological determinants, Journal of Economic Psychology, 2012, 33 (3), pp. 628641

[16] Obschonka, M., Silbereisen, R.K., Cantner, U., Goethner, M. Entrepreneurial self-identity: Predictors and effects within the theory of planned behavior framework, Journal of Business and Psychology, 2015, 30 (4), pp. 773794

[17] Saeed, S., Yousafzai, S., Yani- DeSoriano, M. \& Muffatto, M. The Role of Perceived University Support in the Formation of Students' Entrepreneurial Intention, October, Journal of Small Business Management, 2015, Vol. 53, Issue 4, pp. 1127-1145

[18] Fayolle, A., Liñán, F., \& Moriano, J. Beyond entrepreneurial intentions: values and motivations in entrepreneurship. International Entrepreneurship and Management Journal, 2014, 10, pp. 679-689.

[19] Turton, N., Herrington, M. Global Entrepreneurship Monitor South. Africa; UCT Graduate School of Business: Cape Town, South Africa 2012.

[20] Guerrero, M., Peña-Legazkue, The effect of intrapreneurial experience on corporate venturing: Evidence from developed economies. International Entrepreneurship Management Journal, 2013, 9, pp. 397-416.

[21] Shirokova, G., Osiyevskyy, O. Bogatyreva, $\mathrm{K}$. Exploring the intention-behavior link in student entrepreneurship: Moderating effects of individual and environmental characteristics. European Management Journal, 2016, 34, pp. 386-399.

[22] Liñán, F., Fayolle A. A systematic literature review on entrepreneurial intentions: Citation, thematic analyses, and research agenda, International Entrepreneurship and
Management Journal, 2015, 11 (4), pp. 907933.

[23] Thompson, E.R. Individual Entrepreneurial Intent: Construct Clarification and Development of an Internationally Reliable Metric. Entrepreneurship Theory and Practice, 2009, 33, pp. 669-694.

[24] Oftedal, E.M., Iakovleva, T.A., Foss, L. University context matter: An institutional perspective on entrepreneurial intentions of students. Educational Training, 2018. 60, pp. 873-890.

[25] Fitzsimmons, J. R., Douglas, E.J. Interaction between feasibility and desirability in the formation of entrepreneurial intentions, Journal of Business Venture, 2011, 26, pp. 431440.

[26] Gonzales, M. A.. J., Kobylińska, U. Influence of personal variables on entrepreneurial intention: a comparative study between Poland and Spain, Engineering Management in Production and Services, 2019, 11(1), pp. 68-79.

[27] Haydam, N., Purcarea, T., Edu, T., Negricea, I.C. Explaining satisfaction at a foreign tourism destination - an IntraGenerational approach. Evidence within Generation Y from South Africa and Romania, Amfiteatru Economic Journal, 2017, 45, pp. 528-543.

[28] Duffett, R., Petros, D.M., Negricea, I.C., Effect of YouTube Marketing Communication on Converting Brand Liking into Preference among Millennials Regarding Brands in General and Sustainable Offers in Particular. Evidence from South Africa and Romania, Sustainability, 11, p. 604

[29] Kautonen, T., Van Gelderen, M., Tornikoski, E.T. Predicting entrepreneurial behaviour: A test of the theory of planned behavior, Applied Economics, 2013, 4, pp. 697707.

[30] Smallbone, D., Welter, F. Cross border entrepreneurship. Entrepreneurship and Regional Development, 2012, 24, pp. 95-104.

[31] Engle, R.L., Schlaegel, C., Dimitriadi, N. Institutions and entrepreneurial intent: A crosscountry study. Journal of Developing Entrepreneurship, 2011, 16, pp. 227-250.

[32] Kobylińska, U., Martinez Gonzales, J.A. Influence of the personal variables on the intention of entrepreneurship. A comparative study between Poland and Spain, Engineering Management in Production and Services, 2019, 11(1), pp. 68-79. 
[33] Ferreira, J.J., Raposo, M.L., Rodrigues, R.G., Dinis, A., Paço, A.D. A model of entrepreneurial intention: An application of the psychological and behavioral approaches. Journal of Small Business Entrepreneurship, 2012, 19, pp. 424-440.

[34] Moriano, J.A., Gorgievski, M., Laguna, M., Stephan, U., Zarafshani, K. A Cross-cultural approach to understanding entrepreneurial intention. Journal of Career Development, 2011, 39, pp. 162-185.

[35] Abdullah, N., Hadi, N.U., Dana, L.P. The nexus between entrepreneur skills and successful business: A decompositional analysis. International Journal of Entrepreneurship Small Business, 2018, 34, pp. 249-265.

[36] Hui, C., Kuen, T., Chen, P. The entrepreneurial process: An integrated model. International Entrepreneurship and Management Journal, 2014, 10, pp. 727-745. [37] Ajzen, I., \& Fishbein, M. The influence of attitudes on behaviour. In: D. Albarracín, B. T. Johnson, \& M. P. Zanna (ed.), The handbook of attitudes New York: Erlbaum, Mahwah, 2005, pp. 173-221.

[38] Tomczyk, D., Lee, J., \& Winslow, E. Entrepreneurs' personal values, compensation, and high growth firm performance. Journal of Small Business Management, 2013, 51(1), pp. 66-82.

[39] Kerr, S.P., Kerr W.R. \& Xu T. Personality Traits of Entrepreneurs: A Review of Recent Literature, Foundations and Trends ${ }^{\circledR}$ in Entrepreneurship, 2018. Vol. 14, No. 3, pp 279356.

[40] Wyrwich, M. Entrepreneurship and the intergenerational transmission of values. Small Business Economics, 2015. 45(1), pp. 191-213.

[41] Banerski, T., Przedsiębiorczość akademicka. Raport $\mathrm{z}$ badania, PARP, Warszawa, 2009 pp. 66-67.

[42] Kibler E. Formation of Entrepreneurial Intentions in a Regional Context, Entrepreneurship and Regional Development, 2013, 3-4 (25), pp. 293-323.

[43] Rogoff E. G. \& Heck R. K. Z. Evolving Research in Entrepreneurship and Family Business: Recognizing Family as the Oxygen that Feeds the Fire of Entrepreneurship, Journal of Business Venturing, 2003, 5 (18), pp. 559566.

[44] Dyer W. G. Jr. The entrepreneurial experience, San Francisco: Jossey-Bass, 1992.
[45] Ismail, M., Khalid, S.A., Othman, M., Jusoff, H.K., Rahman, N.A., Kassim, K.M. \& Zain, R.S. Entrepreneurial intention among Malaysian undergraduates. International Journal of Business and Management, 2009, 4(10), pp. 34-44.

[46] Isenberg D. The entrepreneurship ecosystem strategy as a new paradigm for economic policy: Principles for cultivating entrepreneurship. Institute of International European Affairs, Dublin, Ireland, 2011.

[47] Gelard, P. \& Saleh, K.E. Impact of some contextual factors on entrepreneurial intention of university students. African Journal of Business Management, 2011, 5(26), pp. 1070710717.

[48] Fayolle A., Gailly B. \& Lassas-Clerc N. Assessing the Impact of Entrepreneurship Education Programmes: A New Methodology, Journal of European Industrial Training, 2006, 9 (30), pp.701-720

[49] Bae T. J., Qian S., Miao C. \& Fiet J. O. Entrepreneurship Education and Entrepreneurial Intententions: A Meta-Analytic Review, Entrepreneurship Theory and Practice, 2014, 2 (38), pp.217-254.

[50] Peterman, N.E. \& Kennedy, J. 2003. Enterprise education: Influencing students' perceptions of entrepreneurship. Entrepreneurship Theory and Practice, 28(2), 129-144.

[51] Sarstedt, M.; Ringle, C.M.; Smith, D.; Reams, R.; Hair, J.F. Partial least squares structural equation modeling (PLS-SEM): A useful tool for family business researchers. Journal of Family Business Strategy, 2014, 5, pp.105-115.

[52] Oftedal, E.M., Iakovleva, T.A., Foss, L. 2018. University context matter: An institutional perspective on entrepreneurial intentions of students. Education and Training, 60, pp. 873890.

[53] Liñán, F., Chen, Y. Development and crosscultural application of a specific instrument to measure entrepreneurial intentions. Entrepreneurship Theory and Practice, 2009, 33(3), pp. 593-617.

[54] Miranda, F.J., Chamorro-Mera, A., Rubiob, S. Academic entrepreneurship in Spanish universities: An analysis of the determinants of entrepreneurial intention, European Research on Management and Business Economics, 2017, 23, pp. 113-122.

[55] Goethner, M., Obschonka M., Silbereisen, R.K., Cantner U. Scientists' transition to 
academic entrepreneurship: Economic and psychological determinants, Journal of Economic Psychology, 2012, 33 (3), pp. 628641.

[56] Fini R., Grimaldi R., Marzocchi G.L., The Determinants of Corporate Entrepreneurial Intention within Small and Newly Established Firms, Entrepreneurship and Practice, Vol. 36, issue 2, pp. 387-414.

[57] Tsordia Ch., Papadimitriou D., The Role of Theory of Planned Behaviour on Entrepreneurial Intention of Greek Business Students, International Journal of Synergy and Research 2015, 1(4), pp. 23-37.

[58] Jin, Q., Gilmartin, S. K. Sheppard, S.D. Chen, H.L., Comparing Engineering and 20 Business Undergraduate Students' Entrepreneurial Interests and Characteristics, The Journal of Engineering Entrepreneurship, 2015, 6(2), pp. 1-24.

\section{Creative Commons Attribution License 4.0 (Attribution 4.0 International, CC BY 4.0)}

This article is published under the terms of the Creative Commons Attribution License 4.0 https://creativecommons.org/licenses/by/4.0/deed.en_US

\section{Appendix 1 Construct, items and statements}

\begin{tabular}{|c|c|c|}
\hline Construct & Item & Statement \\
\hline \multirow[t]{4}{*}{ A (attitude) } & Q24A & I am a supporter of entrepreneurship \\
\hline & Q26A & Entrepreneurship has a positive impact on the social and economic development of the country \\
\hline & Q27A & Entrepreneurship is a value in itself \\
\hline & Q29A & I value entrepreneurship as a value \\
\hline \multirow{3}{*}{$\begin{array}{l}\text { PC (Perceived } \\
\text { control) }\end{array}$} & Q30PC & I would be successful if I started a company \\
\hline & Q31PC & I would not be afraid to start a company \\
\hline & Q33PC & I would feel safe if I started a company \\
\hline \multirow{3}{*}{$\begin{array}{l}\text { SN } \\
\text { (Subjective } \\
\text { norm) }\end{array}$} & Q25SN & My family would accept that I am an entrepreneur \\
\hline & Q23SN & My friends would accept the fact that I am an entrepreneur \\
\hline & Q18SN & I need to be internally motivated (e.g. a desire for a professional career, the need for continuous learning) \\
\hline \multirow[t]{3}{*}{ I (Intention) } & Q35I & I already have sufficient motivation to start a business \\
\hline & Q19I & It is very likely that I will be an entrepreneur in the future \\
\hline & Q16I & I intend to create a company in the future \\
\hline \multirow{5}{*}{$\begin{array}{l}\text { BE (Business } \\
\text { environment) }\end{array}$} & Q15BE & In order to create a company, the possibilities and assistance of the entrepreneurial environment are necessary \\
\hline & Q13BE & In order to create a company, it is necessary (e) the appropriate technological development of the country \\
\hline & Q11BE & In order to create a company, it is necessary to innovate and develop entrepreneurship in the country \\
\hline & Q10BE & A good supply / demand ratio is necessary to form a business \\
\hline & Q8BE & Government subsidies are required to form a business \\
\hline (Public & Q5PP & In order to create a company, it is necessary to have an appropriate tax policy of the state \\
\hline \multirow[t]{3}{*}{ Policy) } & Q4PP & A good economic situation in the country is necessary to create a company \\
\hline & Q2PP & A government policy that favors entrepreneurship is necessary to create a business \\
\hline & Q1PP & In order to set up a company, the country must be in a good financial position \\
\hline \multirow[t]{3}{*}{ E (Education) } & Q14E & Additional entrepreneurship training after graduation is required to form a company \\
\hline & Q12E & In order to create a company, it is necessary to study entrepreneurship in universities \\
\hline & Q3E & To start a business, it is imperative that entrepreneurship is learned early in education \\
\hline
\end{tabular}

Source: own research 